\title{
Critical Discourse Analysis Norman Fairclough on ASN Social Movements in the Instagram Community @abdimuda_id
}

\author{
Asti Prasetyawati \\ Universitas Indonesia \\ J1. Salemba Raya No.4, RW.5, Kenari, Kec. Senen, Kota Jakarta Pusat, DKI Jakarta, 10430, Indonesia; \\ e-mail: asti.prasetyawati01@ui.ac.id
}

\begin{abstract}
Civil Servant in Indonesia (ASN) has a bad stigma in society. This could decrease the level of public trust in ASN as well as the confidence level of young ASN for their profession. Based on these problems, various movement communities which called themselves as young ASNs were formed, one of which was the Abdimuda Indonesia (@abdimuda_id). As a movement community, Abdimuda Indonesia formed as a medium for young ASN from all regions in Indonesia to jointly develop themselves and maintain positive idealism in order to break down the negative stigma of ASN that already exists. Through Norman Fairclough's Critical Discourse Analysis (CDA) and Barthes' semiotic analysis, this qualitative study wanted to analize the text cracks which formed from framing alignment behind the discourse of ASN in @ abdimuda_id. The results indicate that contents uploaded by @abdimuda_id has a tendency to reflect positive values related to ASN which used by Abdimuda Indonesia to do social change and transforming the negative stigma of ASN into a better image.
\end{abstract}

Keywords: Movement community, framing alignment, critical discourse analysis, semiotics, Abdimuda Indonesia

Article History: Received: 01/07/2021; Revised: 04/12/2021; Accepted: 04/12/2021; Published: 30/12/2021

How to Cite (MLA 7th): Prasetyawati, Asti. “Critical Discourse Analysis Norman Fairclough on ASN Social Movements in the Instagram Community @abdimuda_id." Hortatori Jurnal Pendidikan Bahasa dan Sastra Indonesia 5.2 (2021): 97-106. Print/Online. Copyrights Holder: Asti Prasetyawati. First Publication: Hortatori Jurnal Pendidikan Bahasa dan Sastra Indonesia (2017).

This work is licensed under a Creative Commons Attribution-ShareAlike 4.0 International License.

\section{Pendahuluan}

Pelayanan yang buruk, birokrasi berbelit, dan suka memanfaatkan fasilitas negara di luar tugas merupakan beberapa contoh dari stigma yang melekat pada diri PNS atau yang saat ini lebih sering disebut sebagai ASN (Aparatur Sipil Negara). Stigma buruk ini akan berakibat pada buruknya citra ASN di mata masyarakat dan menyebabkan menurunnya tingkat kepercayaan masyarakat terhadap ASN. Berdasarkan UU Nomor 5 tahun 2014 tentang Aparatur Sipil Negara, ASN adalah profesi bagi Pegawai Negeri Sipil (PNS) dan Pegawai Pemerintah dengan Perjanjian Kerja (PPPK) yang bekerja pada instansi pemerintah.

Sebagai perbandingan dengan profesi ASN di negara lain, beberapa negara seperti Singapura, China, Jepang, Inggris, Amerika, Malaysia, Prancis, dan Australia juga memiliki profesi ASN di negaranya dengan tugas dan tanggung jawab yang beragam. Misalnya di Inggris, ASN tidak hanya bekerja sesuai dengan bidang yang dipilih karena mereka juga memiliki kewajiban untuk melayani masyarakat secara langsung, contohnya dengan cara membantu anak-anak menyeberang jalan dan membantu mendorong kursi roda disabilitas di ruang publik.

Di Indonesia, seorang ASN akan diberikan beberapa tugas dalam bentuk tugas negara atau suatu jabatan pemerintahan dan digaji berdasarkan peraturan perundang-undangan. Dalam undang-undang tentang ASN tersebut juga tertulis bahwa ASN berfungsi sebagai pelaksana kebijakan publik, pelayan 
98 Critical Discourse Analysis Norman Fairclough on ASN Social Movements in the Instagram Community @abdimuda_id

publik, serta sebagai perekat dan pemersatu bangsa. Dalam hal pelayanan publik, ASN dituntut untuk dapat memberikan pelayanan yang profesional dan berkualitas. Poin inilah yang sering menjadi bahan evaluasi masyarakat karena dianggap masih kurang baik.

Sebelumnya, tim peneliti dari UI-CSGAR telah melakukan survei mengenai persepsi masyarakat tentang profesionalitas dan rebranding ASN pada tahun 2019. Berdasarkan hasil penelitian tersebut, sebanyak 58\% responden mengaku lebih sering mendapatkan berita negatif terkait kinerja ASN. Berita negatif yang dimaksud meliputi praktik KKN/pungli (pungutan liar), tidak disiplin, penyalahgunaan wewenang, tidak profesional dan kinerja rendah, skandal, tindakan radikal dan/atau kriminal, tidak netral dalam politik, dan lain sebagainya (UI-CSGAR).

Berbagai penilaian miring dan banyaknya keluhan yang dilayangkan pada kinerja ASN ini pada dasarnya telah menjadi indikasi yang memperkuat bahwa jumlah ASN profesional masih tergolong sedikit dan di bawah standar yang diharapkan (Ashari). Sebelumnya, pemerintah melalui Kementerian Pemberdayagunaan Aparatur Negara telah melakukan rebranding ASN. Melalui UU No. 5 tahun 2014, ASN diharapkan dapat mengaktualisasikan lima nilai dasar ASN yaitu, Akuntabilitas, Nasionalisme, Etika Publik, Komitmen Mutu, dan Anti Korupsi (ANEKA).

Beragam pelatihan dan seminar telah banyak digelar demi menumbuhkan nilai-nilai dasar tersebut dalam diri ASN. Namun, stereotip kinerja ASN yang buruk sudah terlanjur menempel pada label ASN, dan baik secara langsung maupun tidak langsung turut berpengaruh pada kinerja dan mutu ASN. Hal ini sejalan dengan Teori Labeling yang digagas oleh Becker (1963). Teori ini menyebutkan bahwa meskipun pada awalnya perilaku menyimpang dapat bersumber dari berbagai sebab dan kondisi, jika seorang individu telah diberi label atau didefinisikan sebagai penyimpangan, maka ia akan dihadapi dengan masalah baru yang berasal dari reaksi diri dan orang lain terhadap stereotip negatif (stigma) yang melekat padanya (Becker, 1963; Bernburg, 2009; Knutsson, 1977). Berbagai stigma buruk yang melekat pada profesi ASN ini, tak jarang membuat ASN muda menjadi malu untuk mengakui bahwa dirinya bekerja sebagai ASN.

Dari permasalahan tersebut dan dengan didukung oleh perkembangan teknologi informasi dan komunikasi yang semakin mumpuni, terbentuklah beragam komunitas pergerakan, baik online maupun offline, yang menamakan dirinya sebagai ASN muda. Organisasi komunitas yang beranggotakan ASN muda dari seluruh Indonesia ini berdiri dengan nafas yang rata-rata sama yaitu ingin mendobrak stigma negatif ASN dan mengubahnya menjadi citra yang baik agar dapat kembali dipercaya oleh masyarakat.

Salah satu organisasi ASN muda yang menjadi objek dalam penelitian ini adalah Abdimuda Indonesia (@abdimuda_id). Abdimuda Indonesia merupakan organisasi non-profit yang menjadi wadah bagi ASN muda di seluruh Indonesia. Abdimuda Indonesia memiliki keinginan untuk mendorong pola pikir cerdas dan kontributif pada ASN, khususnya ASN muda (mulai dari generasi milenial), sebagai pelayan bangsa. Berbeda dengan organisasi komunitas ASN muda lainnya, Abdimuda Indonesia berangkat dari rasa percaya bahwa generasi muda yang tergabung menjadi Abdi Negara telah memasuki sebuah era baru dengan peluang dan tantangan yang semakin dinamis. Dari sana, Abdimuda Indonesia ingin memfasilitasi para ASN muda untuk dapat berperan aktif dalam agenda pembangunan Indonesia agar Indonesia dapat menjadi negara yang maju dan bermartabat. Berbagai bentuk konten dan kegiatan telah Abdimuda Indonesia lakukan untuk mewujudkannya. Mulai dari memberikan pelatihan online yang berkolaborasi dengan Indika Foundation (Yayasan Indika Untuk Indonesia), rutin mengadakan pertemuan online sebagai bentuk pelatihan dan berbagi pengalaman, memfasilitasi ASN muda untuk membuat buku, hingga rutin membuat konten kreatif seputar ASN di media sosial.

Selain situs web, Abdimuda Indonesia juga aktif pada berbagai platform media sosial, diantaranya adalah Instagram, Facebook, dan Youtube. Lewat berbagai platform ini, Abdimuda Indonesia baik secara langsung maupun tidak langsung, membangun gerakan yang bertujuan untuk mendobrak stigma negatif ASN. Instagram, melalui akun @abdimuda_id, merupakan platform yang paling sering digunakan oleh Abdimuda Indonesia dalam menyebarkan konten-konten pergerakannya. Lewat platform @abdimuda_id, peneliti ingin mengkaji lebih jauh mengenai retak teks yang terbentuk dari framing alignment (pergerakan yang dibangun melalui framing) di balik wacana ASN yang ditampilkan oleh akun Instagram tersebut.

Sebelumnya, terdapat beberapa penelitian terdahulu terkait gerakan massa yang dikaji melalui teori framing dan teori gerakan sosial. Salah satunya adalah penelitian yang dilakukan oleh Jamil (2018) yang berfokus pada gerakan sosial dalam perspektif framing dengan studi kasus isu mengenai korupsi di Indonesia. Menggunakan teknik pengumpulan data melalui analisis teks, serta dilengkapi dengan wawancara mendalam, Jamil (2018) menganalisis teks pada koran Kompas dan Media Indonesia terkait isu 
yang ia angkat. Hasilnya, framing media yang positif mampu menggiring opini dan perspektif publik terhadap isu tersebut serta menentukan sisi mana yang lebih disukai. Lebih dekat lagi dengan penelitian ini, Eren-Erdoğmuş \& Ergun (2017) mengkaji gerakan sosial yang dilakukan lewat media sosial. Berdasarkan penelitiannya, media sosial terbukti strategis untuk memulai, mengorganisir, dan mengkomunikasikan gerakan sosial.

Dari banyak penelitian sebelumnya, kita dapat simpulkan bahwa media sosial dianggap sebagai platform yang strategis dalam hal memulai, mengorganisir, dan mengkomunikasikan gerakan sosial. Selain itu, selaras dengan konsep framing, bingkai yang dibentuk oleh media, baik positif ataupun negatif, akan mempengaruhi persepsi publik terhadap isu yang diangkat. Melalui kajian ilmu Analisis Wacana Kritis Norman Fairclough, penelitian ini akan dispesifikkan dengan merumuskan pertanyaan penelitian sebagai berikut: Bagaimana makna ASN Muda ditampilkan lewat konten Instagram komunitas @abdimuda_id dan digunakan untuk melakukan perubahan sosial?

Tujuan penelitian ini adalah untuk memahami makna penggambaran ASN yang ditampilkan oleh akun Instagram komunitas @abdimuda_id. Penelitian ini ingin melihat praktik sosial yang sedang berlangsung lewat tiga dimensi Norman Fairclough, yaitu dimensi tekstual, dimensi praktik produksi teks, dan dimensi sosial budaya dalam akun media sosial tersebut. Selain itu, penelitian ini juga ingin mencoba mengelaborasi nilai-nilai pergerakan yang ingin dibawa oleh @abdimuda_id dalam rangka mendobrak stigma negatif ASN.

Hasil dari penelitian ini diharapkan dapat bermanfaat sebagai sumbangsih studi ilmu komunikasi dalam mempelajari kajian analisis teks dan media khususnya media sosial Instagram sebagai salah satu wadah pergerakan yang memungkinkan dan dinilai efektif di era digital. Selain itu, penelitian ini juga diharapkan dapat memberikan perspektif baru maupun ide segar bagi instansi pemerintahan dalam hal melakukan rebranding citra ASN untuk kembali menjadi baik dan dipercaya oleh masyarakat luas. Diharapkan juga penelitian ini dapat memberikan inspirasi bagi pembaca dalam hal melakukan pergerakan guna memperbaiki situasi dan kondisi ke arah yang lebih baik.

\section{Metode}

Penelitian ini menggunakan tradisi semiotika dengan metode penelitian Critical Discourse Analysis (CDA). Semiotika adalah ilmu mengenai tanda, di sini tanda dianggap sebagai bagian dari realitas sosial dan berdiri untuk suatu arti tertentu (West and Turner). Tanda (teks/wacana) akan memiliki arti yang berbeda bergantung pada konteks dan orang yang menggunakannya. Melalui tradisi semiotika, peneliti ingin memahami makna dari teks yang dibuat oleh akun Instagram komunitas@ @abdimuda_id sebagai bentuk pergerakan sosial.

Proses analisis dalam penelitian ini menggunakan Semiotika Barthes untuk mempelajari makna tanda dimana peran pembaca dalam memaknai tanda menjadi penting, memandang bahwa tanda bekerja melalui mitos atau nilai-nilai sosial dan kebudayaan, serta menganggap bahasa sebagai sistem tanda yang mencerminkan asumsi-asumsi dari masyarakat tertentu dalam waktu tertentu (Barthes). Semiotika Barthes mengkaji wacana melalui dua tingkatan bahasa, yaitu denotasi dan konotasi. Selain itu, peneliti juga menggunakan metode analisis wacana kritis (AWK) Norman Fairclough untuk menganalisis wacana pada level naskah beserta konteksnya. Melalui metode ini, peneliti ingin memahami 'realitas' di balik teks melalui penelusuran konteks produksi teks, konsumsi teks, dan aspek sosial budaya yang mempengaruhi pembuatan teks (Fairclough, 1995; Hamad, 2007).

Analisis krisis digunakan sebagai sebuah upaya untuk memberikan penjelasan teks yang memiliki tujuan tertentu untuk memperoleh apa yang diinginkan (Susanti et al., 2019). Analisis wacana kritis Norman Fairclough melihat teks di media sebagai wacana dengan konteks yang melibatkan proses produksi dan interpretasi, praktik wacana, dan praktik sosio-kultural (Fairclough, "Critical Discourse Analysis"). Tujuan utama dari melakukan analisis wacana kritis Norman Fairclough adalah untuk memberikan penjelasanpenjelasan yang lebih tepat melalui analisis linguistik terkait perubahan sosial melalui wacana dan hubungannya dengan perubahan lain (Fairclough, "Critical Discourse Analysis"). Menurut Fairclough, diskursus berperan dalam konstruksi identitas sosial, relasi sosial, serta sistem pengetahuan dan makna (ideasional) (Munfarida). Pendekatan Norman Fairclough dapat menganalisis teks secara lengkap karena berusaha untuk menyatukan tiga tradisi (Jorgensen and Phillips), yaitu:

1. analisis tekstual secara linguistik (mikrostruktural) yang meliputi representasi, relasi, dan identitas, 
100 Critical Discourse Analysis Norman Fairclough on ASN Social Movements in the Instagram Community

@abdimuda_id

2. dimensi praktik interpretif dalam produksi teks (meso-struktural) yang meliputi produksi, distribusi, dan konsumsi teks, dan

3. tradisi praktik sosial budaya (makro-struktural) yang meliputi situasional, institusional, dan sosial.

Penelitian ini menggunakan pendekatan kualitatif dengan paradigma kritikal. Pendekatan kualitatif dipilih karena bertujuan untuk mengeksplorasi dan memahami makna individu dan kelompok dalam sebuah wacana yang dikaitkan dengan masalah sosial atau manusia (Creswell). Penelitian ini juga dilakukan dengan menggunakan paradigma kritikal karena penelitian ini bertujuan untuk membongkar atau mengkritik suatu tatanan sosial yang telah ada. Melalui paradigma kritis, penelitian ini bergerak dengan semangat pergerakan untuk memperjuangkan ketidakadilan, penindasan, kekuasaan, dominasi linguistik, dan sebagainya (West and Turner).

Penelitian ini dilakukan dengan cara menganalisis konten yang diunggah pada akun Instagram komunitas@abdimuda_id sejak Oktober 2019 (konten Instagram pertama) hingga Mei 2021. Target penelitian ini adalah konten unggahan berbentuk gambar pada akun Instagram @ abdimuda_id sebagai salah satu komunitas pergerakan ASN muda yang selama dua tahun belakangan ini cukup aktif menyebarkan teks terkait branding citra baru ASN. Konten yang diteliti berjumlah 321 gambar. Konten berbentuk gambar dipilih karena mengandung teks berupa tulisan dan gambar tidak bergerak sebagai objek utama yang diteliti.

Setelah melakukan studi dokumen, sebagai awalan peneliti melakukan pemindaian terkait keseluruhan konten gambar pada akun @abdimuda_id. Setelah itu, peneliti akan memilih beberapa konten pada Instagram @abdimuda_id yang dianggap paling mencolok, tidak mengandung promosi, serta mengandung makna-makna pergerakan untuk dianalisis menggunakan pisau analisis wacana kritis Norman Fairclough dan Semiotika Barthes. Pemilihan konten tersebut didasari pada jenis konten, muatan konten, dan instrumen teks yang terkandung di dalam konten tersebut.

\section{Hasil dan Diskusi}

Instagram komunitas@abdimuda_id cukup sering mengunggah konten dengan frekuensi unggahan adalah 1 -3 hari per konten. Beberapa kali @ abdimuda_id mengunggah sebanyak 2 buah konten dalam satu hari tergantung pada situasi dan momen yang sedang terjadi pada saat itu. Konten yang diunggah pun memiliki format yang cukup beragam, mulai dari format foto/gambar, animasi, hingga video. Peneliti menggunakan 321 konten berbentuk foto/gambar tidak bergerak dari akun @ abdimuda_id untuk diteliti. Dari sejumlah konten tersebut terdapat enam kategori konten, yaitu 1) promosi dan kegiatan Abdimuda sejumlah 150 gambar/kolase, 2) gambar/foto tanpa teks sejumlah 12 gambar, 3) gambar/foto bermuatan lelucon dan/atau sindiran berjumlah 42 gambar, 4) gambar hari peringatan berjumlah 50 gambar, 5) gambar dengan informasi berjumlah 39 gambar/kolase, dan 6) kutipan atau kata mutiara berjumlah 17 gambar.

Sebagai bahan analisis, peneliti mengelompokkan konten berdasarkan makna denotasi dan konotasi melalui semiotika Barthes. Menurut Barthes (1968), denotasi yang juga disebut dengan sistem makna pertama merupakan hubungan antara penanda dan petanda pada realitas. Biasanya makna denotasi telah disepakati secara konvensional dan juga disebut sebagai makna yang sebenarnya. Contoh denotasi adalah gambar bendera berwarna merah dan putih. Sedangkan konotasi adalah sistem makna kedua yang ada di balik teks, terbentuk karena adanya interaksi antara teks dengan emosi serta nilai-nilai kebudayaan. Makna konotatif juga disebut sebagai makna interpretif. Melalui penelitian ini, peneliti menganalisis kontenkonten yang telah dipilih tersebut dengan menggunakan metode analisis wacana kritis Norman Fairclough dan Semiotika Barthes terkait wacana ASN yang dibentuk dengan hasil sebagai berikut:

\section{Analisis Tekstual (Mikrostruktural)}

Analisis teks Fairclough meliputi tiga elemen dasar yaitu representasi, relasi, dan identitas. Berdasarkan analisis teks terhadap ketiga konten di atas, peneliti menemukan bahwa ASN direpresentasikan sebagai individu yang aktif dan berdaya guna. Dalam konten ini terdapat dua alat yang digunakan @abdimuda_id dalam merepresentasikan wacana ASN, yaitu penggunaan gambar dan diksi. Seperti pada unggahan gambar bertemakan Hari Kartini tanggal 21 April 2021 (lihat Gambar 1.). Postingan ini merupakan kolase yang berisi 3 buah gambar. Pada gambar pertama dalam postingan ini, terlihat dua tokoh animasi perempuan berseragam korpri (seragam PNS), satu orang ASN digambarkan dengan tangan mengepal yang bisa direpresentasikan sebagai cerminan nilai semangat dan individu yang aktif. Sedangkan satu orang ASN lainnya yang digambarkan sedang memegang mikrofon bisa direpresentasikan bahwa ASN juga berdaya guna. 

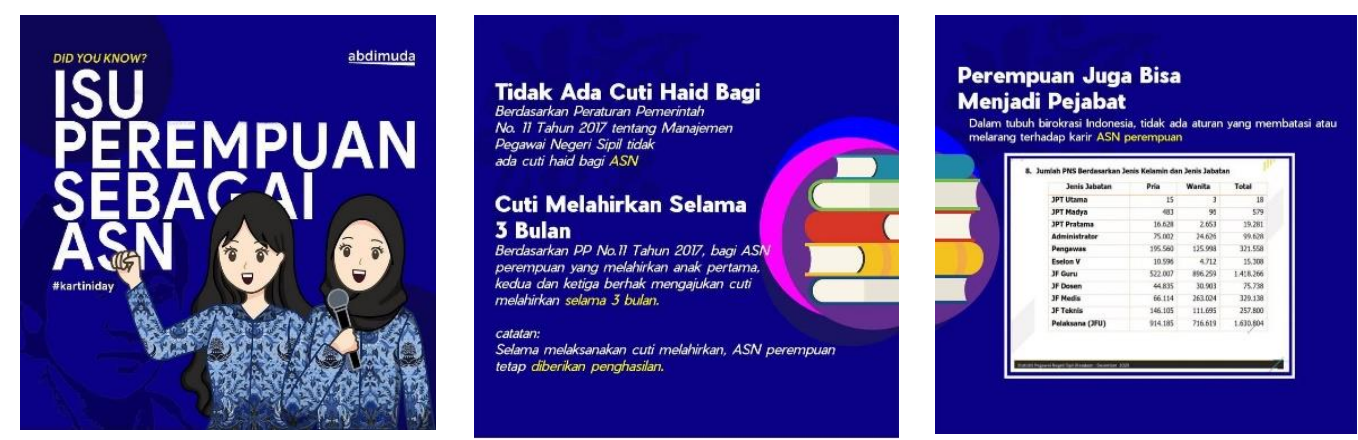

Gambar 1. Kolase konten @abdimuda_id dengan tema Hari Kartini tanggal 21 April 2021 (urutan gambar dari kiri ke kanan)

Penggambaran animasi ASN ini juga senada dengan unggahan konten lainnya baik untuk tokoh laki-laki maupun perempuan. Berikut adalah tabel analisis representasi gambar terkait pemaknaan tanda denotatif-konotatif berdasarkan Semiotika Barthes dalam unggahan gambar yang dilakukan @abdimuda_id secara keseluruhan.

Tabel 1. Analisis semiotika Barthes pada unggahan konten @abdimuda_id

\begin{tabular}{ll}
\hline Denotatif & Konotatif \\
\hline Tokoh animasi perempuan dan laki-laki & Seragam Korpri merupakan \\
berseragam Korpri & seragam yang digunakan oleh \\
& ASN. Penggambaran tokoh \\
& animasi yang terlihat masih muda \\
& mencerminkan generasi muda. Hal \\
& ini menunjukkan bahwa \\
& $@$ abdimuda_id menyasar para \\
& ASN muda sebagai audiens utama.
\end{tabular}

Tokoh animasi dengan tangan mengepal

Tokoh animasi memegang mikrofon, buku catatan, dan pena

Tokoh animasi dan foto orang dengan wajah tersenyum
Berdasarkan penelitian Hung and Labroo (2010), mengepalkan tangan dapat membantu seseorang meningkatkan kontrol diri dan memunculkan tekad. Hal ini juga dapat memicu rasa semangat. Dengan begitu, penggambaran tokoh animasi yang mengepalkan tangan dibuat untuk menunjukkan nilai semangat dan aktif dalam diri ASN Muda.

Mikrofon, buku catatan, dan pena merupakan alat-alat yang biasa digunakan untuk berkarya. Dengan menampilkan ketiga gambar alat tersebut, @abdimuda_id ingin mengunjukkan jiwa ASN Muda sebagai abdi negara yang berdaya guna.

Mayoritas image yang ditampilkan oleh@abdimuda_id melukiskan wajah yang tersenyum. Senyum adalah lambang keceriaan atau kebahagiaan (Hartono and Sugalih, 2019). Dengan ini, makna yang ingin ditampilkan oleh 
102 Critical Discourse Analysis Norman Fairclough on ASN Social Movements in the Instagram Community @abdimuda_id

Tokoh animasi dengan mata menyala dengan api negara

Tokoh animasi berdiri tegak dengan tangan yang mengacung tinggi

Tokoh animasi dan foto orang memegang bendera merah putih

Foto orang melakukan aktivitas sosial

Foto orang menggunakan masker

Foto orang sedang berolahraga

Foto konten dengan menggunakan tokoh/artis terkenal (contoh Emily Cooper, Lee Min Ho, Khaby Lame, dan sebagainya) dalam konten lelucon @abdimuda_id adalah pancaran kebahagiaan ASN Muda yang juga bisa dikaitkan dengan rasa bangga mereka terhadap pekerjaannya.

Api Semangat Bela Negara adalah salah satu semangat yang diusung oleh instansi pemerintahan kepada para pegawainya. Penggunaan ikon api pada konten @abdimuda_id mewakili semangat kepemudaan dan antusiasme.

Dalam Kamus Besar Bahasa Indonesia, berdiri tegak melambangkan kebangkitan dan sikap sigap. Penggambaran tokoh animasi yang berdiri tegak dengan tangan mengacung mencerminkan sikap pemuda yang sigap dan siap bangkit.

Bendera merah putih merupakan simbol jati diri bangsa Indonesia. Penggambaran bendera merah putih pada konten ingin menunjukkan bahwa ASN cinta tanah air.

Kegiatan sosial mencerminkan sifat berbakti kepada masyarakat. Dengan begitu, konten aktivitas sosial yang ditampilkan oleh @abdimuda_id adalah gambaran dari ASN yang peduli dan berbakti dalam melayani publik.

Penggunaan masker merupakan salah satu anjuran dalam protokol kesehatan dalam rangka pandemi Covid-19. Hal ini mencerminkan bahwa ASN mendukung anjuran Pemerintah untuk menggunakan masker di saat pandemi Covid-19.

Olahraga mencerminkan tubuh yang sehat dan jiwa yang kuat. Konten olahraga dalam @abdimuda_id ingin memberikan gambaran bahwa ASN Muda sehat dan tidak malas untuk bergerak.

Tokoh-tokoh tersebut merupakan aktor/aktris yang sedang terkenal saatini.@abdimuda_id menyisipkan orang terkenal dalam kontennya untuk menggambarkan sifat ASN Muda yang dinamis dan mengikuti tren. 
Makna denotasi dan konotasi juga tercermin melalui pilihan diksi yang digunakan. Misalnya, dalam konten yang sama, yaitu konten Hari Kartini, untuk pemilihan diksi @abdimuda_id menggunakan "Perempuan Juga Bisa Menjadi Pejabat" kemudian diikuti dengan penjelasan judul, yaitu "Dalam tubuh birokrasi Indonesia, tidak ada aturan yang membatasi atau melarang terhadap karir ASN perempuan". Hal ini dapat diartikan bahwa dalam birokrasi ASN, baik perempuan atau laki-laki mempunyai kesempatan yang sama untuk menduduki posisi tinggi dan berpengaruh. Sehingga secara tidak langsung, konten ini ingin mendorong para ASN untuk terus berkarya dan bekerja sebaik mungkin untuk menjadi seorang pemimpin, terlepas dari jenis kelamin dan peran gendernya.

Pemilihan diksi lainnya seperti "ASN baru semangat baru”, "ASN siap bantu”, "September jadi leader", "ASN masa kini harus jago investasi”, dan sebagainya juga mencerminkan bentuk pergerakan yang dibentuk melalui framing ASN. Dengan menggunakan diksi seperti ini, Abdimuda ingin membentuk imej baru ASN sebagai pemuda yang bersemangat, cerdas, dan siap untuk menjadi pemimpin. Pemilihan diksi senada pun beberapa kali diulang oleh Abdimuda sebagai usaha untuk merombak imej lama ASN yang buruk. Hal ini sejalan dengan teori kultivasi dimana paparan media yang terus menerus dapat mempengaruhi konsepsi penerima tentang dunia nyata (Shrum, 2017). Selain itu terdapat juga diksi seperti "Tidak boleh mudik, tidak apa-apa" sebagai bentuk sikap ASN yang siap mendukung program Pemerintah untuk tidak mudik di kala pandemi. Kalimat ini mencerminkan ASN sebagai pegawai yang selalu menempatkan urusan orang banyak (social distancing) di atas urusan pribadinya (kebutuhan untuk pulang ke kampung halaman).

Elemen relasi dan identitas dapat dilihat dari pemilihan gambar, diksi, dan data yang ditampilkan. Unsur teks dalam konten ingin menunjukan relasi antara informasi yang terkandung pada konten tersebut dengan audiensnya, yakni para ASN. Sehingga baik dalam gambar animasi yang memakai seragam korpri, pemilihan diksi 'pejabat' yang khas akan birokrasi, dan penjabaran data Peraturan Pemerintah No. 11 Tahun 2017 sengaja dipilih untuk menonjolkan identitas ASN sekaligus untuk menimbulkan kesan relasi yang dekat dengan audiensnya. Hal ini dilakukan agar konten tersebut memiliki engagement yang kuat dengan audiensnya.

\section{Analisis Praktik Produksi Teks (Meso-struktural)}

Analisis praktik produksi teks terdiri dari dimensi produksi, konsumsi, dan juga distribusi teks. Akun Instagram komunitas @abdimuda_id memiliki pengikut sejumlah 10 ribu akun yang mayoritas adalah akun individu yang bekerja sebagai ASN di berbagai Kementerian dan Lembaga Non Kementerian di seluruh Indonesia. Akun ini dijalankan oleh satu divisi media sosial berjumlah 4 orang yang keseluruhannya merupakan anggota dari komunitas Abdimuda Indonesia. Abdimuda Indonesia adalah organisasi nonprofit yang berdiri secara independen tanpa disponsori oleh pihak mana pun. Segala bentuk kerja sama yang terjalin dengan komunitas Abdimuda Indonesia bersifat simbiosis mutualisme baik dari segi publikasi maupun pertukaran materi presentasi. Hal ini membuat akun @abdimuda_id tidak memiliki tekanan khusus dari suatu pihak tertentu yang dapat mendikte mengenai segala jenis konten yang akan diunggah dalam akun Instagram @abdimuda_id.

Setiap konten yang diunggah oleh akun @abdimuda_id merupakan editorial konten yang disusun langsung oleh divisi media sosial Abdimuda Indonesia yang tema kontennya disusun berdasarkan jadwal tertentu. Proses pemilihan dan kurasi konten juga dilakukan secara internal dalam divisi tersebut. Sedangkan distribusi dan konsumsi teks dilakukan di media sosial Instagram dan Whatsapp grup untuk beberapa konten yang dianggap membutuhkan ruang publikasi lebih, seperti konten acara webinar dan sebagainya. Untuk konten-konten lainnya yang bersifat umum (konten informasi, hari perayaan, lelucon, dan kutipan) hanya didistribusikan dan dapat dikonsumsi secara umum melalui platform Instagram baik melalui Instagram feeds maupun Instagram stories. Abdimuda Indonesia juga memanfaatkan kolom komentar sebagai sarana untuk berinteraksi dengan audiensnya. Seperti pada konten Hari Kartini yang telah dibahas sebelumnya, menuai 4 buah komentar dari audiens. Komentar tersebut jenisnya beragam, di antaranya adalah komentar yang menyuarakan dukungannya terhadap ASN perempuan untuk dapat menduduki jabatan tinggi dan ada juga yang memberikan pertanyaan terkait informasi yang dipaparkan dalam konten. Melalui kolom komentar ini, dapat dipahami bahwa informasi yang disampaikan melalui konten tersebut dapat dimengerti oleh audiens.

Mayoritas konten yang mendulang banyak komentar adalah konten yang berisi lelucon. Hal ini juga dijadikan salah satu cara Abdimuda dalam menarik perhatian para followers-nya untuk lebih peka 
terhadap isu-isu yang berkaitan dengan ASN. Salah satu konten yang mendapatkan jumlah likes dan komentar terbanyak adalah konten kolase terkait pencapaian ideal ASN di umur 25 (lihat gambar 2.). Kala itu, topik 'pencapaian pada umur 25 tahun' sedang menjadi tren di media sosial. Konten ini mendapat 773 kali likes dan 135 komentar. Dalam konten ini Abdimuda menyelipkan ANEKA sebagai lima nilai dasar aktualisasi ASN yang dikemas dengan nada humoris sehingga menjadi menarik. Dengan cara ini, Abdimuda telah mempopulerkan nilai-nilai ASN kepada audiensnya.
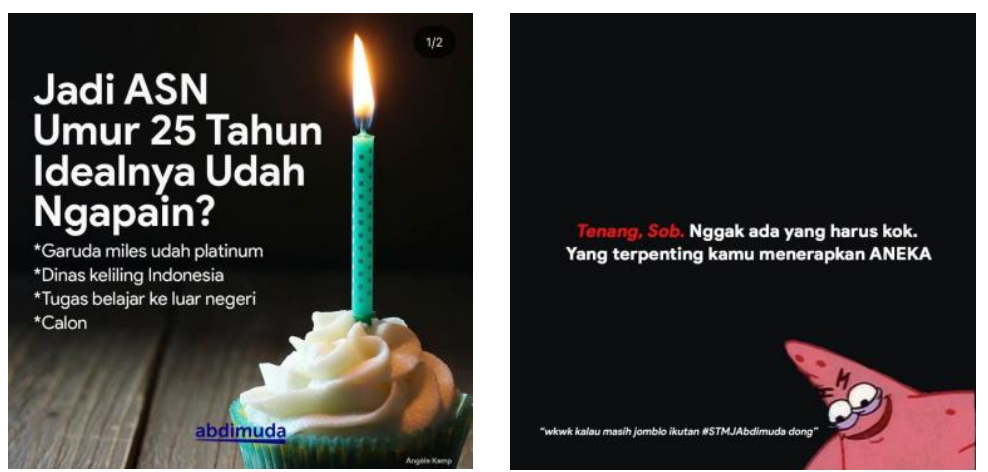

Gambar 2. Kolase konten @abdimuda_id tanggal 11 Mei 2021 (urutan gambar dari kiri ke kanan)

\section{Analisis Praktik Sosial Budaya (Makro-struktural)}

Analisis praktik sosial budaya Fairclough memiliki tiga level analisis yaitu pada tingkat situasional, institusional, dan tingkat sosial. Pada tingkat situasional setiap media massa, termasuk ke dalamnya media sosial Instagram, mengangkat sebuah isu atau peristiwa yang mengandung nilai berita. Mayoritas konten Instagram Abdimuda dibuat dengan memanfaatkan momen dalam situasi yang sedang terjadi. Seperti pada konten Hari Kartini, nilai berita yang diangkat adalah aktualitas dan kedekatan. Pada level situasional, konten tersebut memanfaatkan momentum Hari Kartini (21 April 2021) yang identik dengan perempuan untuk membagikan informasi mengenai ASN perempuan. Hal ini juga tercermin dalam pemilihan tokoh animasi di gambar pertama yang kedua tokohnya digambarkan dengan ciri khas perempuan (berambut panjang dan berkerudung). Membahas perihal ASN perempuan di Hari Kartini telah menjawab nilai aktualitas berita yang disajikan.

Pada level institusional, konten Hari Kartini memuat informasi mengenai Peraturan Pemerintah yang merupakan peraturan yang penting dan berdampak langsung pada ASN. Dengan ini, @abdimuda_id telah melibatkan konteks institusional pada pembuatan kontennya. Hal ini juga sekaligus menunjukkan nilai kedekatan konten dengan audiens. Sedangkan pada level sosial, seringkali isu perempuan dalam pekerjaan mendapatkan perhatian yang besar dari masyarakat. Melalui konten tersebut, @abdimuda_id ingin mendukung para ASN perempuan di Indonesia untuk terus berprestasi dan mendorongnya agar dapat menjadi pemimpin dalam birokrasi.

\section{Simpulan}

Melalui analisis Fairclough dan Semiotika Barthes, peneliti menyimpulkan bahwa konten-konten yang diunggah oleh akun Instagram @abdimuda_id memiliki kecenderungan untuk mencerminkan nilainilai positif terkait ASN, di antaranya adalah nilai semangat, aktif, kesetaraan gender, berjiwa pemimpin, dan dinamis. Nilai-nilai positif ini sengaja dibingkai dan diangkat oleh Abdimuda Indonesia lewat pemilihan gambar, foto, dan diksi dari setiap kontennya sebagai salah satu langkah yang ditempuh untuk mengubah stigma negatif masyarakat terhadap ASN. Abdimuda Indonesia juga hadir sebagai medium bagi ASN muda di seluruh Indonesia untuk dapat berkumpul, saling bertukar informasi, dan berbagai materi yang berhubungan dengan pengembangan diri ASN. Dengan menjadi medium bagi para ASN muda, Abdimuda Indonesia juga memberikan kekuatan dan semangat persatuan sekaligus hadir sebagai pengingat bahwa mereka tidak berjalan sendirian di dalam kungkungan stigma negatif ASN. Abdimuda Indonesia ingin mengajak ASN muda untuk selalu berdiri di atas idealisme yang positif dengan semangat melayani publik yang baik sesuai dengan yang Tan Malaka (Pahlawan Nasional Indonesia) katakan, yaitu"Harta yang paling berharga yang dimiliki pemuda adalah idealisme”. Dengan cara ini, Abdimuda Indonesia 
melakukan perubahan sosial untuk merombak stigma negatif ASN menjadi citra yang lebih baik dan dapat diandalkan.

Penelitian ini memiliki keterbatasan terkait fokus dari masalah yang diteliti, dimana penelitian hanya berfokus pada makna ASN yang ditampilkan lewat konten Instagram komunitas@abdimuda_id berbentuk foto dan gambar dalam melakukan perubahan sosial merombak stigma negatif ASN. Di samping foto dan gambar, @abdimuda_id juga memiliki bentuk konten lainnya seperti video singkat di Instagram, artikel di website, podcast di Spotify, dan video di Youtube. Hal tersebut memungkinkan adanya temuantemuan lain yang dapat digali lagi dalam mengkaji konsep framing alignment yang digunakan oleh komunitas Abdimuda Indonesia dalam menciptakan imej baru untuk ASN sebagai bentuk dari perubahan sosial. Untuk itu, diperlukan adanya penelitian lanjutan terkait framing alignment yang dilakukan oleh Abdimuda Indonesia dan komunitas ASN lainnya dengan bahasan yang lebih beragam dalam fokus masalah.

\section{Ucapan Terima Kasih}

Penulis mengucapkan terima kasih kepada dosen pengampu Mata Kuliah Seminar Analisis Teks Media Departemen Ilmu Komuniasi Universitas Indonesia, Prof. Ibnu Hamad dan Udi Rusadi, yang telah membimbing penulis dalam menyelesaikan artikel penelitian ini. Penulis juga mengucapkan terima kasih kepada Komunitas Abdimuda Indonesia beserta segenap tim yang telah membantu memberikan dukungan informasi yang berharga kepada penulis.

\section{Daftar Rujukan}

Ashari, Edy Topo. "Memahami Karakteristik Pegawai Negeri SIpil Yang Profesional.” Jurnal Kebijakan Manajemen PNS, vol. 4, no. 2, 2010, pp. 1-11.

Barthes, Roland. Elements of Semiology. 1st ed., Hill and Wang, 1968, https://monoskop.org/images/2/2c/Barthes_Roland_Elements_of_Semiology_1977.pdf.

Becker, Howard. "Howard Becker 1963.Pdf." Outsiders: Studies in the Sociology of Deviance, Free Press, 1963, pp. 1-39.

Bernburg, Jón Gunnar. Labeling Theory. no. June, Springer Science, 2009, doi:10.1007/978-1-4419-02450 .

Creswell, John W. "Research Design Qualitative, Quantitative, and Mixed Method Approaches." Sage Publications, edited by Vicki Knight, 4th ed., Sage Publication Ltd., 2014, http://marefateadyan.nashriyat.ir/node/150.

Eren-Erdoğmuş, Irem, and Sinem Ergun. "The Impact of Social Media on Social Movements: The Case of Anti-Consumption." Online Communities as Agents of Change and Social Movements, no. March, ResearchGate, 2017, doi:10.4018/978-1-5225-2495-3.ch009.

Fairclough, Norman. "Critical Discourse Analysis." The Routledge Handbook of Discourse Analysis, no. February, 2013, pp. 9-20, doi:10.4324/9780203809068-8.

Fairclough, Norman. "Critical Discourse Analysis." Africa's Potential for the Ecological Intensification of Agriculture, 1st ed., vol. 53, no. 9, Longman Group Limited, 1995.

Hamad, Ibnu. "Lebih Dekat Dengan Analisis Wacana." Mediator: Jurnal Komunikasi, vol. 8, no. 2, 2007, pp. 325-44, doi:10.29313/mediator.v8i2.1252.

Hartono, Dudi, and Asep Sugalih. "Makna Simbol Senyum Pada Iklan Lay' S Di Televisi (Semiotics Analyisis of Charles Sanders Pierce)." Jurnal Perspektif Komunikasi, vol. 3, no. 1, 2019, pp. 4146.

Hung, Iris W., and Aparna A. Labroo. "From Firm Muscles to Firm Willpower: Understanding the Role of Embodied Cognition in Self-Regulation." Journal of Consumer Research, vol. 37, no. 6, 2011, pp. 1046-64, doi:10.1086/657240.

Jamil, Achmad. "Social Movements in Framing Perspectives: A Study on Corruption Case Issues in Indonesia." Jurnal Komunikasi Indonesia, vol. 7, no. 2, 2018, doi:10.7454/jki.v7i2.9989.

Jorgensen, Marianne, and Louise Phillips. "Discourse Analysis as Theory and Method." Sage Publications, 1st ed., Sage Publication Ltd., 2002, doi:10.4135/9781849208871.

Knutsson, Johannes. Labeling Theory. 3rd ed., vol. 196, no. 4289, The National Swedish Council for Crime Prevention, 1977.

Munfarida, Elya. "Elya Munfarida." Komunika, vol. 8, no. 1, 2014, pp. 1-19, 
http://www.ejournal.iainpurwokerto.ac.id/index.php/komunika/article/view/746.

Shrum, L. J. "Cultivation Theory: Effects and Underlying Processes." The International Encyclopedia of Media Effects, 2017, pp. 1-12, doi:10.1002/9781118783764.wbieme0040.

Susanti, Khikmah, et al. "Wacana Kritis Fairclough Dalam Teks Iklan Mana Tau: Indian Royal Cofee." Hortatori: Jurnal Pendidikan Bahasa Dan Sastra Indonesia, vol. 3, no. 2, 2020, pp. 111-17, doi:10.30998/jh.v3i2.223.

UI-CSGAR, Tim Peneliti. Indeks Persepsi Masyarakat Tentang Profesionalitas Dan Rebranding ASN Tahun 2019. 2019, https://csgar.ui.ac.id/data/assets/publication/publication_16tCsD.pdf.

West, Richard, and Lynn H. Turner. "Introducing Communication Theory." McGraw-Hill Companies, edited by Michael Ryan, 4th ed., vol. 53, no. 9, Frank Mortimer, 2010. 